\title{
Effectiveness of urdu reading braille characters with the help of tactile and visual clues
}

\author{
Abdul Hamid ${ }^{*}$, Muhammad Saleem Mohsin ${ }^{2}$, Muhammad Noman Khalid ${ }^{3}$ \\ ${ }^{1}$ Government College University Faisalabad, Pakistan \\ ${ }_{2}$ Assistant Professor University of Agriculture, Faisalabad, Pakistan \\ ${ }^{3}$ Government College women university Faisalabad, Pakistan
}

*Corresponding author: a.hamid150gb@gmail.com

\begin{abstract}
This study shows that most sighted can learn whole-word Braille reading. To this knowledge, this is the first demonstration that adults with an intact visual system can learn such a complex tactile task, given the right motivation and method. Five objectives were formulated for this study. To identify the effects of tactile training on the children was the fourth objective. To explain the effects of training based visual clues on the children was the fifth objective. This study was experimental in nature. Two experimental groups were designed. It was seen that some senses enhanced in case of the deprivation of a sights sense. In the visually impaired personal the tactile sense is clear due to the visual impairment. Similarly visual sense became more tactile tasks in deaf students. Reading and penning Braille has been a priority for Hadley Institute for the Blind and Visually Impaired since its introduction in 1920. The day of Braille course is our democratic course. The modification is associated with potentially adaptive neural reorganization.
\end{abstract}

Keywords: Tactile Clues, Visual Clues, Urdu, Braille Character, Neural Reorganization

\section{ARTICLE INFORMATION}

Received: 23-Jan-2019

Revised:5-Mar-2019

Accepted: 15-Mar-2019

\section{INTRODUCTION}

It was seen that some senses enhanced in case of the deprivation of a sights sense. In the visually impaired personal the tactile sense is clear due to the visual impairment. Similarly visual sense became more tactile tasks in deaf students. Reading and penning Braille has been a priority for Hadley Institute for the Blind and Visually Impaired since its introduction in 1920. The day of Braille course is our democratic course. The modification is associated with potentially adaptive neural reorganization (Bhattacharjee, Amanda, Lisak, Vargas, \& Goldreich, 2010) while other reported greater special abjection in the end of the finger of early visually impaired readers (Van Boven, Hamilton, Kauffman, Keenan, \& Pascual-Leone, 2000) the involvement of occipital regions in tactual distinction goals appear to be useable related to tactile Braille reading in early visually impaired children'sBut not for those who have sight or who became sightless latter. Braille gets reading writing note winning and communication possible for blind and deaf-blind users (Homma, Ino, Kuroki, Izumi, \& Ifukube, 2004)

The Braille first principal is based upon a cell that is composed of six points, arrange in two towers of three points each. Each Braille sign of the first principal or other symbol, such as a comma, is formed busing one or more of the point that are consists in the Braille cell that fits under fingertips (Howse, 2006)

The letters are raised on exceptional composition either by hand with a instrument called way which is pressed into the paper done holes in a perforate frame, or by employment a Braille writing machine, such as a Perkins Braille, orb an raised attached to a computer.

Origin of Braille is French and there is no Tactual signing is a usual average of communicating put-upon by citizenry with both a sighted and visually impaired (Deaf blindness), which is based on a voice communication or other system of manual communication. Tactual if you are a tactile beginner, learn by felling by finger and by working. Students keep in mind things through movement by physically. Student is "hands-on" learner who choose to touch, move, visually impaired or standoff what student find out and student be given to learn well when or so type of physical movement is tangled(Jiménez et al., 2009).

Tactile icons are a modern way of communicating method acting complete balance statistical and acoustic reply. Which are planned communications which may be worn to correspond to learner blindly? Transient prepared post via feeling by figure is fruitful in fields like that calculating where visions are short or in interfaces for visually impaired person that have not visionary able. The research shows the conditions of opinion and works with hepatic stimulus and draws a plan of Tractions \& limited latent application.

Helen Keller said about Louis Braille, "In our way, we, the blind, are as indebted to Louis Braille as mankind is to Gutenberg(Bickel, 2015)."In 1829, Louis Braille published an article One perception about the individuals is that with a sensory canal compensate about the individuals skills when one uses the intact senses. visual impaired person often show their lackness to be a superior one in action and handling, for example verb imposing, oral memory vocal reading and frequency difference (Alary et al., 2009; Gougoux, Zatorre, Lassonde, Voss, \& Lepore, 2005)

Reading depends on a consistent network of cortical regions across individuals and 77 writing systems (Krafnick et al., 2016). A key part of this network 78 is the so-called blind word form field, placed in the left ventral occipital temporal cortex. The VWFA is situated among regions involved in visual object 80 recognition, such as the bursiform face area and the are hippocampus place area, and is thought to support the recognition of written letters and word forms(Cohen et al., 2002). The VWFA is an example of experience-dependent cortical specialization: 83 preferential responses to letters and words are only found in literate adults (Dehaene et al., 2010) visual impaired person 
are particular capable to stand out in singular complex tactile tasks, for example Braille reading (Millar, 2003) it copy indecipherable to what extant Braille reading can be learnt without visual deprecation in the case of relatively simple tactile tasks, such as discriminating grating orientation, several studies show that the blind's superior performance can be explained by experience-dependent mechanisms, as blind subjects have more experience in using touch in their everyday lives(Van Boven et al., 2000). Braille reading, however, is a complex skill and prolonged visual deprivation is thought to greatly enhance its acquisition. In blind people, the onset of blindness largely determines proficiency in Braille reading in adulthood. Congenitally and early blind individuals are able to achieve Braille reading speed of 80 120 words-per-minute and more whereas late-blind people usually read two to three times slower and many of them struggle to learn Braille at all (Bola et al., 2016; Burton et al., 2002)

Here we enrolled sighted adults in a 9-month Braille reading course. We show that most sighted adults can learn whole-word Braille reading, given the right method and motivation. The pace of Braille acquisition in our sighted subjects was comparable to that of blind children learning Braille reading in school. The problem is stated that communication gap between parents and visually impaired chider" and to show the parent's role in language development of visually impairment children an special children needs. Anecdotal evidence suggests that visual input might be Detrimental to the acquisition of the Braille reading skill. Sighted subjects who learn to read Braille usually do sousing sight rather than touch and blindfolding partial blind children seems to speed up Braille learning. As most Braille reading material is printed in contracted Braille, it is necessary for Braille readers to learn contracted Braille (D'Andrea, 2009) That depend on the area learning system or school, the sum of extra duration which is assigned can change; though, in Quebec, Canada, the Ministry of Education, Leisure \& Sports "MELS" has modulated the extraperiodgiven for Braille learners by restraining enhancement of the time forest to a utmost extra time which is equal to the $1 / 3$ of the normal time. The chance have, though never provide the reply anyone have predictable, \& they have some organized study for the method of Braille learning, while the nearly revised by (Foulke, 1982) obviously gives. Analyzing the impact for various different efficient deficiencies, to somewhat that of various eye problems, on reading and spelling (Van Boven et al., 2000)

\section{Statement of the study}

Braille reading, and may be gained by visionary matters. Here we observed twenty sighted persons; most of them are Braille trainers and supervisor, in a 7-month Braille reading program. In start of program, all matters were immature in tactile Braille reading practice. At the end of the program, most of the students were capable to read all Braille words at a average speed of 7 words-per-minute. Case with little tactile sharpness did not vary considerably in Braille reading speed than the rest of the participants, which shows that little tactile sharpness is not a restrictive factor of learning Braille, basic step of learning. Our observation results that maximum sighted persons may train in all word Braille reading, with a good technique and a significant amount of inspiration. The mature sensor motor system can thus adjust, to some extent, to very multipart tactile matter without visual deficiency.

\section{Significance of Study}

This study informs the argument about Losses versus which observer the blind person's special abilities. the past experience show , that observable topic's can high Lighted the concerned common hepatic job such as the differentiating of the reparation of hepatic embossed signs.

\section{Objectives of the study}

- To compare the effect of tactile trading and visual clues skill the Braille characters reading.

- To identify the effects of tactile training on the children

\section{Research Questionr of the study.}

1:What are the differences in the tactile reading and visual clues skill in reading characters?

2 :What are the effects of tactile training on the children?

\section{RESEARCH METHODOLGY}

The Research was about following methodology.

Research Design

This study was experimental in nature. Two experimental groups were designed. One group was given the training of visual clues. The second group was provided the tactile training. The group reprehensive of the research design was as under'

$\begin{array}{lllll}\text { Experimental Group. I } & \mathrm{R} & \mathrm{O}_{1} & \mathrm{X}_{1} & \mathrm{O}_{2} \\ \begin{array}{l}\text { Experimental Group. II } \\ \mathrm{O}=\text { OBSERVATION }\end{array} & \mathrm{R} & \mathrm{O}_{2} & \mathrm{X}_{2} & \mathrm{O}_{4} . \\ \mathrm{R}=\text { Randomization } \\ \mathrm{O}_{1} & \mathrm{R} & & \\ \mathrm{O}_{2} & \mathrm{R} & \text { Pre-test assessment of the visually clues } \\ \mathrm{O}_{3} & \mathrm{R} & \text { Post-test of the visual clues } \\ \mathrm{O}_{4} & \mathrm{R} & \text { Pre-test of the tactical } \\ \mathrm{X}_{1} & \mathrm{R} & \text { Post-test of the tactical } \\ \mathrm{X}_{2} & \mathrm{R} & \text { Experiment of the visual clues } \\ & & \text { Experiment of the tactical }\end{array}$

\section{Population of study}

The aim of the study was to search out closer impressive of the Braille Learner student on the achievement of M.A / M .Ed Special education students.

The population of study was based on teachers of visual impaired students.

\section{Delimitation of the study;}

The study was delimited to;

M.A Med, Special education students of Allam Iqbal Open University Islamabad.

The study was further delimiated to the students belonged to Faisalabad, Toba Tek Singh and Jhung city or nearly villages and towns.

\section{Sample of the study:-}

The students of the class M.A Special Education (Allam Iqbal Open University Islamabad) were the sample of the study. The research design involved two groups, an experimental group which underwent complete Braille reading was based Urdu between the ages of 16 - 25 years. Above all the subject is strongly Braille reading skills.

The sample consisted of 16 students including 8 students in experimental group (A) and 8 students in the second experimental group (B). All the students belonged to Faisalabad, Toba Tek Singh and hung city or nearly villages and towns. These were taught The Braille. Concepts about Braille were thoroughly learned by the students. Above students were given tests.

Firstly, the researchers of above groups of students have greater access to the subject for an extended period of time. The students of this university and class were preferred over the other classes because most of the students would be available in the workshops for Braille Learning.

Secondly, it is called in our society that the students of Allam Iqbal Open University Islamabad have no concept of Braille reading or writing skill. 


\section{Study Plan}

The study is composed of the effects of tactile and visual learning on the reading abilities of sighted students. The reading abilities will be measured recognizing the characters of Braille the student will be given training with the help tactile and visually clues. The study is composed of three phases.

\section{PHASE I}

In phase I the sample was selected on prescribed criteria. The selected sample was divided into two groups i.e.

Group A and group B

\section{PHASE II}

Phase II was composed of intervention of two groups group A was given test reading Braille with tactile method. The training and exercise were composed of tactile method.

Group was given test about Braille reading with visually clues method. The training and exercise was composed of visually clues in this

\section{IN URDU}

Group A was given test about punctuation.

Group A was given test to Braille reading with tactile method.

Write the following in Braille

- Fragrance of flowers is spreading all around

- Today weather is cloudy

- I am glad to see you

- I will serve according to your desire

\section{IN URDU}

Group II was given test about English alphabets and Group B was given test about Braille reading with visually clues method.

Write the following in Braille

- He has a spacious time to see you

- Teacher seen me

- Students are busy in their study

- $\quad \mathrm{He}$ is a best artesian

\section{PHASE III}

Phase III is composed the post-test of the intervention.

\section{SCORING}

The response of all the subjects during pre test and post test were checked according to key while tests of all students were checked and the students using tactile method obtained maximum score of 7 out of 20 .

The students using visually clues method obtained maximum score of 14 out of 20 .

\section{ANALYSIS OF DATA}

On the basis of the mean of the pre test score, the students of the experimental group A and group B were further divided into subgroups of high and low achievers .students having score more than their relative mean were considered as high achievers group. For calculation of data the means, standard deviations, and difference of means were calculated for each group. Significance of difference between mean square of experimental groups A, experimental group B. The pre-test mean score were subtracted from post-test mean, score to get the mean difference in each individual in both groups I, II

\section{Experiment group 1 (tactile method) in urdu}

\begin{tabular}{cll} 
Table 1: Information of E1 Respondent Test & \\
\hline & Information type & Value \\
\hline 1 & Gender & Female \\
2 & Physical Age & 27 \\
3 & Study level \\
4 & City & MA/M.Ed. Special \\
5 & $\begin{array}{l}\text { Command Following } \\
\text { Braille Reading with Tactile Method } \\
6\end{array}$ & $\begin{array}{l}\text { Good } \\
\text { (Pre-test) }\end{array}$ \\
7 & $\begin{array}{l}\text { Braille Reading with Tactile Method } \\
\text { (Post-test) }\end{array}$ & $65 \%$ \\
8 & $\begin{array}{l}\text { Braille Reading with Tactile Method } \\
\text { (Pre-test Marks) }\end{array}$ & $7 / 20$ \\
9 & $\begin{array}{l}\text { Braille Reading with Tactile Method } \\
\text { (Post-test Marks) }\end{array}$ & $13 / 20$ \\
10 & Time of Reading & $30 \mathrm{Mint}$ \\
\hline
\end{tabular}

The female a represented named SN with physical age 27 year old. The student MA/M.Ed. special education Allama Iqbal open University Islamabad for semester $2^{\text {nd }}$ in practical Braille Crouse code 3601 (Urdu).

According to the table 4.17 pre-test tactile methods a test of a student of class MA/M.Ed. special education had been taken and he will obtained $20 \%$ marks in Braille reading with tactile method (Pretest) 7 marks out of 20 in pre-test and 13in Braille post-test.

Time allowed to student is 30 mints and command following was good.

According to the 4.17 post-test Braille reading with tactile method a test of student of class MA/M.Ed. special education had been taken and he will obtained 13 marks out of 20 at $65 \%$ in Braille reading with tactile method and 11 in Braille post-test.

Table 2: Information of E2 Respondent Test

\begin{tabular}{lll}
\hline & Information type & Value \\
\hline 1 & Gender & Female \\
2 & Physical Age & 25 \\
3 & Study level & MA/M.Ed. Special \\
4 & City & Faisalabad \\
5 & $\begin{array}{l}\text { Command Following } \\
\text { Braille Reading with Tactile Method }\end{array}$ & $25 \%$ \\
6 & $\begin{array}{l}\text { Middle } \\
\text { (Pre-test) }\end{array}$ & $45 \%$ \\
7 & $\begin{array}{l}\text { Braille Reading with Tactile Method } \\
\text { (Pre-test) }\end{array}$ & $\begin{array}{l}\text { Braille Reading with Tactile Method } \\
\text { (Pre-test Marks) }\end{array}$ \\
8 & $\begin{array}{l}\text { Braille Reading with Tactile Method } \\
\text { (Post-testMarks) }\end{array}$ & $11 / 20$ \\
10 & \begin{tabular}{l} 
Time of Reading \\
\hline
\end{tabular} & 30 Mint \\
\hline
\end{tabular}

The female a Represented named NL with physical age 25 year old. The student MA/M.Ed. special education Allama Iqbalopen University Islamabad for semester $2^{\text {nd }}$ in practical Braille Crouse code 3601 (Urdu).

According to the table 4.18 pre -test tactile method a test of a student of class MA/M.Ed. special education had been taken and he will obtained 25\% marks in Braille reading with tactile method (Pretest) 5 marks out of 20 in pre-test and 11 in Braille post-test.

Time allowed to student is 30 mints and command following was middle.

According to the table 4.18 post-test Braille reading with tactile method a test of student of class MA/M.Ed. special education had been taken and he will obtained 11 marks out of 20 at $45 \%$ in Braille reading 
with tactile method (Pre-test) 6 marks out of 20 in pre-test and 11 in Braille (post-test).

\section{Experiment group 2 (tactile method) in urdu}

\begin{tabular}{lll}
\multicolumn{2}{l}{ Table 3: Information of E7 Respondent Test } \\
\hline & Information type & Value \\
\hline 1 & Gender & Male \\
2 & Physical Age & 24 \\
3 & Study level & MA/M.Ed. Special \\
4 & City & Faisalabad \\
5 & Command Following & Good \\
6 & $\begin{array}{l}\text { Braille Reading with Visual Clues } \\
\text { Method (Pre-test) }\end{array}$ & $30 \%$ \\
7 & $\begin{array}{l}\text { Braille Reading with Visual Clues } \\
\text { Method (Post-test) }\end{array}$ & $60 \%$ \\
8 & $\begin{array}{l}\text { Braille Reading with Visual Clues } \\
\text { Method (Pre-test) }\end{array}$ & $6 / 20$ \\
9 & $\begin{array}{l}\text { Braille Reading with Visual Clues } \\
\text { Method (Post-test) }\end{array}$ & $12 / 20$ \\
10 & Time of Reading & $30 \mathrm{Mint}$ \\
\hline
\end{tabular}

The male a represented named NFN with physical age 24 year old. The student MA/M.Ed. special education Allama Iqbal Open University Islamabad for semester $2^{\text {nd }}$ in practical Braille Crouse code 3601 (Urdu).

According to the table 4.31 pre -test tactile method a test of a student of class MA/M.Ed. special education had been taken and he will obtained 30\% marks in Braille reading with tactile method (Pretest) 6 marks out of 20 in pre-test and 12 in Braille post-test.

Time allowed to student is 30 mints and command following was middle.

According to post-test Braille reading with Visual Clues method a test of student of class MA/M.Ed. special education had been taken and he will obtained 12 marks out of 20 at $60 \%$ had been taken and he will obtained 30\% marks in Braille reading with tactile method (Pre-test) 6 marks out of 20 in pre-test and 11 in Braille post-test

Table 4: Information of E8 Respondent Test

\begin{tabular}{lll}
\hline & Information type & Value \\
\hline 1 & Gender & Female \\
2 & Physical Age & 20 \\
3 & Study level & MA/M.Ed. Special \\
4 & City & Faisalabad \\
5 & Command Following & Middle \\
6 & Braille Reading with Visual Clues & $15 \%$ \\
& Method (Pre-test) & \\
7 & $\begin{array}{l}\text { Braille Reading with Visual Clues } \\
\text { Method (Post-test) }\end{array}$ & $50 \%$ \\
8 & $\begin{array}{l}\text { Braille Reading with Visual Clues } \\
\text { Method (Pre-test Marks) }\end{array}$ & $3 / 20$ \\
9 & $\begin{array}{l}\text { Braille Reading with Visual Clues } \\
\text { Method (Post-test Marks) }\end{array}$ & $10 / 20$ \\
10 & Time of Reading & 30 Mint \\
\hline
\end{tabular}

- The female a represented named AZ with physical age 20 year old. The student MA/M.Ed. special education Allama Iqbal open University Islamabad for semester $2^{\text {nd }}$ in practical Braille Crouse code 3601 (Urdu).

- According to the table 4.32 pre -test tactile method a test of a student of class MA/M.Ed. special education had been taken and he will obtained $15 \%$ marks in Braille reading with tactile method (Pre-test) 3 marks out of 20 in pre-test and 10 in Braille post-test.

- Time allowed to student is 30 mints and command following was middle.

- According to the post-test Braille reading with Visual Clues method a test of student of class MA/M.Ed. special education had been taken and he will obtained 10 marks out of 20 at $50 \%$ had been taken and he will obtained $30 \%$ marks in Braille reading with tactile method (Pre-test) 6 marks out of 20 in pretest and 11 in Braille post-test.

\section{SUMMARY}

It was seen that some senses enhanced in case of the deprivation of a sights sense. In the visually impaired personal the tactile sense is clear due to the visual impairment. Similarly visual sense became more tactile tasks in deaf students. Reading and penning Braille has been a priority for Hadley Institute for the Blind and Visually Impaired since its introduction in 1920. The day of Braille course is our democratic course. The modification is associated with potentially adaptive neural reorganization. They are structured messages that can be used to communicate to users non-visually. To this knowledge, this is the first demonstration that adults with an intact visual system can learn such a complex tactile task, given the right motivation and method. Five objectives were formulated for this study. Objective. To identify the effects of tactile training on the children was the second objective. To explain the effects of training based visual clues on the children. This study was experimental in nature. Two experimental groups were designed. One group was given the training of visual clues. The second group was provided the tactile training. The described method was adopted for the improvement of visual and tactile training. The Urdu Braille was improved with the visual clues method.

\section{FINDINGS}

1: according to the post-test Braille reading with tactile method a test of student of class MA/M.Ed. special education had been taken and he will obtain 13 marks out of 20 at $65 \%$ (Table 4.1)

2: according to the post-test Braille reading with tactile method a test of student of class MA/M.Ed. special education had been taken and he will obtain 12 marks out of 20 at $45 \%$ (Tab3)

3 according to post-test Braille reading with Visual Clues method a test of student of class MA/M.Ed. special education had been taken and he will obtain 10marks out of 20 at $60 \%$ (Table 4.3)

4: according to the post-test Braille reading with Visual Clues method a test of student of class MA/M.Ed. special education had been taken and he will obtain 12 marks out of 20 at $50 \%$ (Table 4.4)

\section{CONCLUSION}

The Eight students improved in Urdu Braille Reading with tactile method and Eight students improved Urdu Braille Reading with visually clues method. And One student improved them self in ,Urdu and Braille reading with tactile method.

\section{RECOMMENDATION}

The students, may be exposed with the visually clues and tactile method in the daily school activity

The policy makers may be involved in the process of curriculum development related to visual and tactile method.

The visual clues method and tactile method may be added the curriculum of students in primary level also.

\section{REFERENCES}

Alary, F., Duquette, M., Goldstein, R., Chapman, C. E., Voss, P., La Buissonnière-Ariza, V., \& Lepore, F. (2009). Tactile acuity in the blind: a closer look reveals superiority over the sighted in some but not all cutaneous tasks. Neuropsychologia, 47(10), 2037-2043.

Bhattacharjee, A., Amanda, J. Y., Lisak, J. A., Vargas, M. G., \& Goldreich, D. (2010). Vibrotactile masking experiments reveal accelerated somatosensory processing in congenitally blind braille readers. Journal of Neuroscience, 30(43), 14288-14298. 
Bickel, L. (2015). Triumph over darkness: the life of Louis Braille: Bloomsbury Publishing.

Bola, Ł., Siuda-Krzywicka, K., Paplińska, M., Sumera, E., Hańczur, P., \& Szwed, M. (2016). Braille in the sighted: teaching tactile reading to sighted adults. PloS one, 11(5), e0155394.

Burton, H., Snyder, A. Z., Conturo, T. E., Akbudak, E., Ollinger, J. M., \& Raichle, M. E. (2002). Adaptive changes in early and late blind: a fMRI study of Braille reading. Journal of neurophysiology, 87(1), 589-607.

Cohen, L., Lehéricy, S., Chochon, F., Lemer, C., Rivaud, S., \& Dehaene, S. (2002). Language-specific tuning of visual cortex? Functional properties of the Visual Word Form Area. Brain, 125(5), 1054-1069.

D'Andrea, F. M. (2009). A history of instructional methods in uncontracted and contracted braille. Journal of Visual Impairment \& Blindness, 103(10), 585-594.

Dehaene, S., Pegado, F., Braga, L. W., Ventura, P., Nunes Filho, G., Jobert, A., . . . Cohen, L. (2010). How learning to read changes the cortical networks for vision and language. science, 330(6009), 1359-1364.

Foulke, E. (1982). Reading braille. Tactual perception: A sourcebook, 168.

Gougoux, F., Zatorre, R. J., Lassonde, M., Voss, P., \& Lepore, F. (2005). A functional neuroimaging study of sound localization: visual cortex activity predicts performance in early-blind individuals. PLoS biology, 3(2), e27.

Homma, T., Ino, S., Kuroki, H., Izumi, T., \& Ifukube, T. (2004). Development of a piezoelectric actuator for presentation of various tactile stimulation patterns to fingerpad skin. Paper presented at the The 26th Annual International Conference of the IEEE Engineering in Medicine and Biology Society.

Howse, J. (2006). Unified English braille primer: Australian edition: NSW Department of Education and Training.

Jiménez, J., Olea, J., Torres, J., Alonso, I., Harder, D., \& Fischer, K. (2009). Biography of louis braille and invention of the braille alphabet. Survey of ophthalmology, 54(1), 142-149.

Krafnick, A. J., Tan, L.-H., Flowers, D. L., Luetje, M. M., Napoliello, E. M., Siok, W.-T., . . . Eden, G. F. (2016). Chinese character and English word processing in children's ventral occipitotemporal cortex: fMRI evidence for script invariance. Neuroimage, 133, 302-312.

Millar, S. (2003). Reading by touch: Routledge.

Van Boven, R. W., Hamilton, R. H., Kauffman, T., Keenan, J. P., \& PascualLeone, A. (2000). Tactile spatial resolution in blind Braille readers. Neurology, 54(12), 2230-2236. 